Creative Commons User Licence: CC BY-NC-ND

Abstracted by: EBSCOhost, Electronic Journals Service (EJS),

Google Scholar, Directory of Open Access Journals (DOAJ),

Journal Seek, Scientific Commons, and

Food and Agricultural Organization (FAO)
Journal of Agricultural Extension

Vol.19 (1) June, 2015

ISSN 24086851

http://journal.aesonnigeria.org

http://www.ajol.info/index.php/jae

$\underline{\text { http://dx.doi.org/10.4314.jae.v19i1.4 }}$

\title{
Role of Households in Rabbit Production in Enugu-North Agricultural Zone of Enugu State
}

\author{
Onyinyechi Ifeanyi Ogbonna \\ Department of Agricultural extension \\ University of Nigeria, Nsukka
}

\begin{abstract}
This study assessed households' involvement in rabbit production in Enugu-North Agricultural Zone of Enugu State. It determined rabbit management and breeding practices of respondents, roles of households in rabbit production and constraints associated with rabbit production in the area. Multistage sampling technique was used to select eighty respondents. Data were collected through the use of structured interview schedule and analyzed using percentages, mean scores and standard deviations. Majority (62.55\%) provide feed for their rabbits twice a day. Majority (86.2\%) use paddocks and wooden hutches to construct rabbit house/cages. Adult female and youth/children play less roles in rabbit production. Most perceived constraints were: inadequate/lack of fund $(M=3.97)$, lack of access to foundation stock $(M=3.97)$ and poor knowledge of rabbit production $(M=3.92)$. It was recommended that households involved in rabbit production in the area should be encouraged to increase production through training and increased awareness on prevalence of disease and vaccination of rabbits. Similarly, they should be provided with access to foundation stock and other inputs by government and agricultural organizations like Ministry of Agriculture and Agricultural Development Programme in the area.
\end{abstract}

\section{Introduction}

Micro-livestock such as rabbit, guinea pig, grasscutter, giant rat and pigeons have been suggested as a rapid mean of obtaining animal protein. The human population growth of developing countries including Nigeria is still increasing rapidly. Thus, the search for alternative sources of protein to meet up the needs of the population is imperative. Economic indices indicate that as this population trend continues, more people are to be fed. In order to maximize food production and meet protein requirements in Nigeria, viable options need to be explored and evaluated. Among such alternatives is the use of livestock species that are yet to play a major role in animal production within these countries. Fast-growing livestock such as rabbits possess a number of features that might be of advantage in the small holder subsistence - type integrated farming in developing countries. In developing countries, rabbits emerge as low cost answer to the problems of hunger and under nutrition of the poor rural dwellers (FAO, 2000). Rabbits are unique among small animals for food and commerce. They are adapted for both temperate and tropical environment. 
Creative Commons User Licence: CC BY-NC-ND

Abstracted by: EBSCOhost, Electronic Journals Service (EJS),

Google Scholar, Directory of Open Access Journals (DOAJ),

Journal Seek, Scientific Commons, and

Food and Agricultural Organization (FAO)
Journal of Agricultural Extension

Vol.19 (1) June, 2015

ISSN 24086851

http://journal.aesonnigeria.org

http://www.ajol.info/index.php/jae

Rabbit can supply the needs of an average family and is a suitable and cheaper alternative to some protein sources. Based on the attributes of rabbits they can be easily kept by households for increased protein consumption. The attributes of rabbits include: affordable or low-cost management requirements, small-bodied size, short regeneration interval, fecundity, rapid growth rate, genetic diversity, ability to utilize forage and agricultural by-products, and adaptation over a wide range of ecological environments (Abu, Onifade, Abanikannda, Obiyan, 2008). However, inadequate supply of protein from livestock such as rabbit, cattle, sheep, goat, chicken, require the intensification of effort to improve on the productivity of these animals. Rabbit farming in Nigeria is faced with myriad of problems, which have resulted to a gross shortage of meat to meet up with the population challenge in the country (Nworgu, 2007). The growth rate of the Nigerian agricultural sector is below the potentials of natural and human resources due to high cost of agricultural inputs, poor funding of agriculture, inadequate functional infrastructural facilities, inconsistencies of government agricultural policies, inadequate private sector participation, poor mechanized farming and little or no adoption of some simple agricultural technologies developed by scientists (Nworgu, 2007). Rabbit production in the area is going into extinction since the production is left for the young males in the household. However, households can help to provide labour, time and inputs for intensified rabbit production. Hence, this study sought to assess households' involvement in rabbit production in Enugu-North Agricultural Zone of Enugu State. Specifically, It sought to:

1. determine rabbit management and breeding practices of respondents;

2. ascertain roles of households in rabbit production and

3. identify constraints associated with rabbit production in the area.

\section{Methodology}

The study was carried out in Enugu North Agricultural zone of Enugu state. Enugu North agricultural zone is primarily an agrarian area. The rabbit farmers in the zone constituted the population for the study. The zone is made up of eight blocks; Uzo- Uwani, Udenu, Igbo-Eze North, Nsukka I, Nsukka II, Igbo-Etiti, Uzo-Uwani I and Uzo Uwani II. Four (4) blocks namely, Igbo-Eze South, Igbo-Eze North, Nsukka I and Nsukka II, were purposively selected because they have large rabbit rearers. Each block consists of eight circles and two circles each were randomly selected from each block giving a total of eight (8) circles for the study. From each circle containing eight (8) sub-circles, two (2) sub-circle were randomly selected giving a total of sixteen (16) sub-circles. Farmers rearing rabbit were purposively selected from each of the sub circle giving a total of eighty (80) respondents for the study.

To examine the management practices employed by the respondents, a list of management practices such as feeding, housing, sanitation and breeding practices were provided for the respondents to indicate the one they use. To identify the household role in rabbit production, a list of roles namely feeding, construction/maintenance of hutch, routine cleaning, vaccination, detecting of sick ones and culling were collated. A list of management practices was provided for the respondents to identify the roles performed by adult male, adult female, youth children and all the members. To collect information on the constraints on rabbit production, a list of possible constraints such as inadequate/lack of fund, lack of training in rabbit breeding, lack of access to 
Creative Commons User Licence: CC BY-NC-ND

Abstracted by: EBSCOhost, Electronic Journals Service (EJS),

Google Scholar, Directory of Open Access Journals (DOAJ),

Journal Seek, Scientific Commons, and

Food and Agricultural Organization (FAO)
Journal of Agricultural Extension

Vol.19 (1) June, 2015

ISSN 24086851

http://journal.aesonnigeria.org

http://www.ajol.info/index.php/jae

foundation stock, theft incidence of predator, cost of feed, mortality rate, poor quality of meat, lack of market for rabbits among others was made available. Respondents were asked to indicate the level of perceived seriousness of each constraints on a 4 point Likert-type scale of: to a great extent $=4$, to little extent $=3$, to very little extent $=2$ and to no extent $=1$. These values were summed to obtain 10 and divided to get 2.5. Variables with the mean of greater than or equal to 2.5 would be considered as possible constraints to rabbit production.

\section{Results and Discussions}

\section{Rabbit management and breeding practices of respondents}

\section{Feeding}

Data in Table 1 show that majority $(62.55 \%)$ provide feed for their rabbits twice a day, while $27.5 \%$ feed their rabbits once a day and $2.5 \%$ feed them three times a day. Table 1 also shows that $92.5 \%$ provide forage and kitchen waste, while $40 \%$ feed their rabbit with kitchen wastes and none feed them commercial. The commercial feed is expensive for the small scale rabbit farmer. Most of the respondents rely on forage and kitchen waste since these are obtained at no cost. Rabbit production in developing countries is based on low cost feeding, using locally available feedstuffs (Mailafia, Onakpa and Owoleke, 2010). Such feed sources lack some essential nutrients indicating poor nutrition which result in low growth rate, reproductive inefficiency and their being predisposed to diseases. According to Mailafia et al (2010), Rabbits may be maintained solely on green feeds together with household vegetable waste.

However, careful management and balancing of diets is necessary (Aduku and Olukosi, 1990 in Mailafia, et al., 2010). Although rabbit is by nature herbivorous, growth rate on forage based diets containing high fiber levels will be increasingly curtailed. This is due to the animal's inability to obtain sufficient digestible material to satisfy its energy demands. Alternatively, a protein supplement may be provided, such as vegetable oil seeds or oil seed residues. According to Irlbeck (2001); Samkol and Lukefahr (2008), a balanced diet containing adequate fibre (20$25 \%$ ), minimal starch and optimum protein concentration is important to prevent gastrointestinal distress and improve rabbit production (Irlbeck 2001).

\section{Housing}

Housing constitutes an important factor for a successful rabbit production. Data in Table 1 indicate that $86.2 \%$ of the respondents use paddocks and wooden hutches in construction of rabbits house/cage. This is related to the findings of Hungu, Gathumbi, Maingi and Ng'ang'a (2013), who observed that most farmers housed their rabbits in hutches. According to Mailafia et al. (2010) housing types include the cages, pens, paddocks, underground and insulated housing, and housing made from locally sourced raw materials such as bamboo, while rabbits kept on free range make for themselves houses in holes.

About routine of sanitation of the houses, the respondents show that more than three quarter $(95.9 \%)$ of the respondents periodically clean feeding and watering trough, as well as remove hair from does. This implies that respondents in the area know the harmful effects of diseases but this 
Creative Commons User Licence: CC BY-NC-ND

Abstracted by: EBSCOhost, Electronic Journals Service (EJS),

Google Scholar, Directory of Open Access Journals (DOAJ),

Journal Seek, Scientific Commons, and

Food and Agricultural Organization (FAO)
Journal of Agricultural Extension

Vol.19 (1) June, 2015

ISSN 24086851

http://journal.aesonnigeria.org

http://www.ajol.info/index.php/jae

management will not totally prevent infections in their farm except by use of effective sanitizing solution (Kahn, 2005).

Table 1: Distribution of respondents according to management and breeding practices used in rabbit production

\begin{tabular}{ll}
\hline Variable & Percen \\
\hline Feeding & \\
(a) feeding with green forages (sweet potatoes leaves, carrots, etc) & 92.3 \\
(b) grain or concentrates which include kitchen waste, corn meal & 40 \\
wastes, soybean wastes, bambara nut wastes & \\
(c) Agricultural product such as dried peels, wet milled cereal by & 51.2 \\
products etc &
\end{tabular}

\section{Housing}

(a) Steel/ iron cage $\quad 9.0$

(b) pen

5.0

(c) Underground

(d) paddock/wooden hutches $\quad 86.0$

(e) wire mesh/wood (potato hutches)

\section{Sanitation}

(a) use of NaHCL for sanitation

(b) disinfection of nest boxes between uses

(c) Periodic cleaning of feeder/watering equipments

95.0

(d)Periodic removal of hairs pull out from does

(e) Frequent removal of litters

Breeding

Mating

(a) check 2 or 3 times/week for mating $\quad 90.0$

(b) take the doe to buck for mating $\quad 16.2$

(c) check does for pregnancy after 4 days -

\section{Kindling}
(a) $1-2$
(b) 3-4
(c) no response
0.2

Sources of breeding stock
(a) market
30.0
(b) neighbor
43.8
(c) government
21.2
(d) no response
5.0

Multiple response 
Creative Commons User Licence: CC BY-NC-ND

Abstracted by: EBSCOhost, Electronic Journals Service (EJS),

Google Scholar, Directory of Open Access Journals (DOAJ),

Journal Seek, Scientific Commons, and

Food and Agricultural Organization (FAO)
Journal of Agricultural Extension

Vol.19 (1) June, 2015

ISSN 24086851

http://journal.aesonnigeria.org

http://www.ajol.info/index.php/jae

\section{Breeding/kindling and source of breeding stock}

Majority (90.0\%) of the respondents took their does to bucks for mating while $68.7 \%$ and $25.0 \%$ of the respondents indicated that their rabbits kindle 1-2 and 3-4 rabbits respectively. About 30\% of the respondents source their breeding stock from market while $43.8 \%$ and $21.2 \%$ of the respondents get their breeding stock from neighbors and government agencies respectively. This

implies that the respondents have look litter size and poor fertility and low regenerating rabbits. This may be due to the type of feed given to the rabbits by the respondents.

\section{Roles of household in Rabbit Production}

The distribution of respondents in Table 2 indicates that rabbit production is a household responsibility. All members of the family participated in the production. Though, 53\% were adult male, 21.15 of the respondents were of all genders. Few (18.1\%) and 7.9\% of the respondents were adult females and youths/children respectively. Adult female and youth/children play fewer roles in rabbit production but they participate. Major decisions and activities such as construction/maintenance of hutches, detecting of sick ones and culling, vaccination and decision on type of rabbit were undertaken by adult males. The youths or children mostly cut grasses for the rabbit and clean the pens. The adult females also participate in some activities.

Table 2: Distribution of respondents on roles of household in rabbit production

\begin{tabular}{|c|c|c|c|c|}
\hline Roles & $\begin{array}{l}\text { Adult } \\
\text { male }\end{array}$ & $\begin{array}{l}\text { Adult } \\
\text { female }\end{array}$ & Youth/children & All \\
\hline Vaccination & 96.2 & 3.8 & - & - \\
\hline $\begin{array}{l}\text { Construction/maintenance of } \\
\text { hutch }\end{array}$ & 100 & - & - & - \\
\hline Routine cleaning of hutch & 5.0 & 16.2 & 23.8 & 53.8 \\
\hline $\begin{array}{l}\text { Detecting of sick ones and } \\
\text { culling }\end{array}$ & 63.8 & 20.0 & 3.8 & 12.5 \\
\hline Marketing & 7.5 & 13.8 & 21.2 & 55.0 \\
\hline Decision on type of rabbit & 68.8 & 28.8 & - & 2.5 \\
\hline Record keeping & 62.5 & 20.0 & 10.0 & 3.8 \\
\hline Transporting rabbits & 33.8 & 12.5 & 22.5 & 31.2 \\
\hline Cutting of grasses & 5.0 & 2.5 & 15.0 & 77.5 \\
\hline Diseases treatment & 93.8 & 3.8 & - & 2.5 \\
\hline Take Does to hutch for mating & 52.5 & 23.8 & 3.8 & 20.0 \\
\hline Feeding of rabbits & 3.8 & 7.5 & 18.8 & 70.0 \\
\hline Processing of rabbits & 83.8 & 13.8 & - & 2.5 \\
\hline $\begin{array}{l}\text { Drying a sking on a wooden } \\
\text { drying frame (tanning) }\end{array}$ & 12.5 & 82.5 & 2.5 & 2.5 \\
\hline Testing for pregnancy & 73.8 & 23.8 & - & 2.5 \\
\hline Ear notching & 80.0 & 15.0 & 2.5 & - \\
\hline
\end{tabular}

\section{Constraints Associated with rabbit production}


Creative Commons User Licence: CC BY-NC-ND

Abstracted by: EBSCOhost, Electronic Journals Service (EJS),

Google Scholar, Directory of Open Access Journals (DOAJ),

Journal Seek, Scientific Commons, and

Food and Agricultural Organization (FAO)
Journal of Agricultural Extension

Vol.19 (1) June, 2015

ISSN 24086851

http://journal.aesonnigeria.org

http://www.ajol.info/index.php/jae

Table 3 indicates that the most perceived constraints were: inadequate/lack of fund ( $\mathrm{M}=3.97)$, lack of access to foundation stock $(\mathrm{M}=3.97)$, poor technical know-how on rabbit production $(\mathrm{M}=3.92)$ , lack of interest by government and research institutions $(\mathrm{X}=3.87)$, lack of ready market for rabbit $(\mathrm{M}=3.84)$, high rate of mortality $(\mathrm{M}=3.82)$, high incident of predator/diseases $(\mathrm{M}=3.81)$, poor extension contact $(\mathrm{M}=3.81)$, labour intensive production $(\mathrm{M}=3.61)$, high cost of feeding $(\mathrm{M}=3.38)$, difficulty in feeding especially dry season $(\mathrm{M}=3.27)$.

However, the following were not perceived as serious constraints: poor quality of meat $(M=2.02)$, poor feed conversion efficiency ( $\mathrm{M}=2.10)$, and high risk of theft $(\mathrm{M}=2.4)$. These constraints are similar to those found out by Oseni, Ajayi, Komolafe, Siyanbola, et al (2008) who identified constraints in rabbit production as: capital, space, feed, vermin, theft and lack of foundation stock among others. The standard deviation of less than one for all the responses indicates that the responses did not vary much from the mean. This implies that the respondents had related opinions.

Based on the above constraints, farmers should be encouraged and trained to improve their technical knowhow and their awareness on prevalence of diseasse and vaccinations. Similarly, farmers spend more time to get access to foundation stock because there are no established center to provide the replacement stock. All these clearly indicate the series of constraints which cause decline in rabbits production among the rural households in the agricultural zone.

Table 3: Mean distribution of respondents on constraints associated with rabbit production

\begin{tabular}{lll}
\hline Constraints & Mean Score & Standard Deviation \\
\hline Inadequate/lack of fund & 3.9 & .15 \\
Lack of access to foundation stock & 3.9 & .15 \\
Difficulty in feeding especially during dry season & 3.3 & .71 \\
High risks of theft & 2.4 & .92 \\
High incidence of predators/disease & 3.8 & .47 \\
High rate of mortality & 3.8 & .38 \\
High cost of feed & 3.3 & .70 \\
Poor quality of meat & 2.0 & .91 \\
Lack of ready market for rabbit & 3.8 & .39 \\
Poor technical knowhow on rabbit production & 3.9 & .26 \\
Production is labour intensive & 3.6 & .56 \\
Rabbit production is not lucrative & 3.2 & .94 \\
Poor extension contacts & 3.8 & .42 \\
Lack of interest by government and research institutions & 3.8 & .33 \\
Poor feed conversion efficiency of rabbit & 2.1 & .99 \\
\hline
\end{tabular}

\section{Conclusion and Recommendations}

Rapid growth rate, high reproduction potential, and ability to utilize forage make rabbits an important livestock contributing to meat and protein production in Nigeria. They often have abundant resources of forage, local building materials and labor, all of which can be effectively utilized in rabbit production. The study identified the roles played by different members of the 
Creative Commons User Licence: CC BY-NC-ND

Abstracted by: EBSCOhost, Electronic Journals Service (EJS),

Google Scholar, Directory of Open Access Journals (DOAJ),

Journal Seek, Scientific Commons, and

Food and Agricultural Organization (FAO)
Journal of Agricultural Extension

Vol.19 (1) June, 2015

ISSN 24086851

http://journal.aesonnigeria.org

http://www.ajol.info/index.php/jae

household and constraints in rabbit production in the study area. Some of the constraints included limited access to breeding stock and poor technical knowhow on rabbit production. The study therefore recommends the establishment of rabbit extension programme in the area, aimed at increasing the awareness and adoption of rabbit production. A rabbit breeding center in the agricultural zone is of essence as this will encourage and provide them with improved breeding stock. More so, extension workers should educate the farmers on the alternative of using concentrate to supplement rabbit feeding since the forages available are always seasonal and does not provide sufficient nutrients.

\section{References}

Abu, O. A. (1995), Potential of rabbit production as means of supplying animal protein in Nigeria. Green. Nigeria: Nigerian Association of Agricultural Students, University of Ibadan. Pp 2324.

Ahukanna, C.O. (1990). A survey of rabbit husbandry in Nsukka Local Government Area, B.Agric, Thesis, University of Nigeria, Nsukka.

FAO (2000), World rabbit progress. Nutrition and digestible physiology, Spain.

Igban, M.S. (1990). Farmers capability profiles. In M.S Iben eds. The Nigeria Farmers and agricultural institutions: An assessment of NISER. Ibadan, Nigeria Pp67-92.

Iheukumere, F.C., I.C. Okoli., G.A. Anyanwu and V.O. Esonu. (2005). Growth performance, hematological and serum biochemical constituents of grower rabbit feed microdesmis puberula, Hook Euphorbiaceae. Animal Production.

Irlbeck N A (2001) How to feed the rabbit (Oryctolagus cuniculus) gastro intestinal tract. Journal of Animal Science volume 79 (Electronic Supplement): Pp343-346

Mailafia, S., Onakpa, M.M. and Owoleke O.E (2010). Problems and prospects of rabbit production in Nigeria - a review. Bayero Journal of Pure and Applied Sciences, 3(2): Pp 20 - 25

Lebas, F.P. Condert, R. Rouvier and De Rochambeau, H. (1997). The rabbit Husbandry, Health and production. Food and Agricultural Organization of the United Nations, Rome.

Luke F.S.D. and Cheeke O., (1991). Rabbit project development strategies in subsistence farming system: Practical considerations. Wild Animal Rev. 69, pp26-345.

Ofomata, G.E. (1978). Nigeria in Maps: Eastern States. Ethiope publishing Company Limited, Benin. P.52.

Omele, A. J. Omuetio and Ogunleke O.J. (2005). Performance characteristics of weaned rabbit feed graded levels of dry cassava peel fortified with soyabean residues basal diet. Journal of food, Agriculture and Environment 3, 36-38. 
Creative Commons User Licence: CC BY-NC-ND

Abstracted by: EBSCOhost, Electronic Journals Service (EJS),

Google Scholar, Directory of Open Access Journals (DOAJ),

Journal Seek, Scientific Commons, and

Food and Agricultural Organization (FAO)
Journal of Agricultural Extension

Vol.19 (1) June, 2015

ISSN 24086851

http://journal.aesonnigeria.org http://www.ajol.info/index.php/jae

Oseni, S.O. (2008). Research output in rabbit science and production emanating from Sub-Sharan Africa: Implication for future research and development efforts. In Proc. $9^{\text {th }}$ World Congress, 2008 June, Verona, Italy. 1591-1596.

Oseni S, Ajayi B, Komolafe S, Siyanbola O, Ishola M and Madamidola G (2008). Smallholder rabbit production in south western Nigeria: current status, emerging issues and ways forward' Management and Economy presented at the 9th World Rabbit Congress Verona Italy. Pages 1597-1601 